\title{
POTENSI, TANTANGAN, DAN STRATEGI PEMASARAN KOPI (Studi Kasus Usaha Pengelolaan Kopi Kelompok Wanita Tani Suka Makmur I di Dusun Ngaglik, Desa Pledokan, Kabupaten Semarang)
}

THE POTENTIAL, CHALLENGES, AND MARKETING STRATEGIES OF COFFE (Case Study of Coffe Management Business of Group I Suka Makmur Women Farmers in Ngaglik, Pledokan Village, Semarang Regency)

\author{
Maurinus Junaedi Laka Senda*, Tinjung Mary Prihtanti \\ Fakultas Pertanian dan Bisnis, Universitas Kristen Satya Wacana \\ *E-mail: maurinusjunedi@gmail.com \\ (Diterima 25-06-2021; Disetujui 16-07-2021)
}

\begin{abstract}
ABSTRAK
Penelitian ini bertujuan untuk menganalisis potensi, tantangan dan strategi pemasaran produk kopi yang dilakukan Kelompok Wanita Tani Suka Makmur I. Sumber informasi yang didapat dalam penelitian berasal dari bagian pemasaran sebagai key informant dan ketua Kelompok Wanita Tani Suka Makmur I sebagai informan. Cara pengambilan data awal menggunakan metode wawancara, selanjutnya menggunakan kuesioner untuk mengambil data penelitian. Teknik analisis data dalam penelitian ini menggunakan matriks IFE, EFE, IE, SWOT dan QPSM. Hasil dari penelitian ini adalah Kelompok Wanita Tani Suka Makmur I memiliki 12 faktor kekuatan, 5 faktor kelemahan, 8 peluang, dan 2 faktor ancaman yang dihadapi oleh perusahaan, serta ada 10 alternatif strategi pemasaran yang direkomendasikan untuk Kelompok Wanita Tani Suka Makmur I.
\end{abstract}

Kata kunci: Potensi, Tantangan, Strategi Pemasaran Kopi, Kelompok Wanita Tani Suka Makmur I, SWOT, QSPM

\begin{abstract}
This research aims to: Analyze the potential, challenges, and marketing strategies of coffee products produced by group I of Suka Makmur woman farmers. The source of information obtained from this research came from the key informants of the marketing department and the head of the group I of Suka Makmur women farmer as an informant. The initial data collected by using the interview method, then using a questionnaire to collect more research data. The data analysis technique in this research is used IFE, EFE, IE, SWOT, and QPSM matrices. The results of this study are the group I of Suka Makmur women farmers have 12 strength factors, 5 weaknesses factors, 8 opportunities, and 2 threats factors faced by the company, and 10 alternative marketing strategies are recommended for group I of Suka Makmur women farmers.
\end{abstract}

Keywords: Potential, Challenges, Marketing Strategy for Coffee, Group I of Suka Makmur women farmer, SWOT, QSPM

\section{PENDAHULUAN}

Kelompok Wanita Tani (KWT)

Suka Makmur I adalah sebuah organisasi penghasil kopi yang berada di Dusun Ngaglik RT. II RW. IV, Desa Pledokan, Kecamatan Sumowono, Kabupaten
Semarang. Alasan dibentuknya organisasi ini adalah untuk meningkatkan nilai jual kopi asli di daerah Sumowono, yang selama ini hanya dijual pada tengkulak. Jenis kopi yang diproduksi adalah kopi arabika dan robusta. Jenis 
kopi yang ada di Kelompok Wanita Tani Suka Makmur I ialah kopi biji dan kopi bubuk. Pengelolaan yang dilakukan mulai dari proses penanaman hingga proses pemasaran produk. Kelompok Wanita Tani menjadi salah satu organisasi wanita kopi pertama di Kecamatan Sumowono dan sudah menghasilkan produk kopi bermerek dagang dengan nama Gumuk Dali. Wilayah pemasaran antara lain pasar sumowono, balai penyuluh pertanian dan kepada konsumen. Peneliti mengambil subjek penelitian Kelompok Wanita Tani Suka Makmur I karena belum ada perusahaan atau organisasi wanita di Jawa Tengah yang mengelola produk kopi.

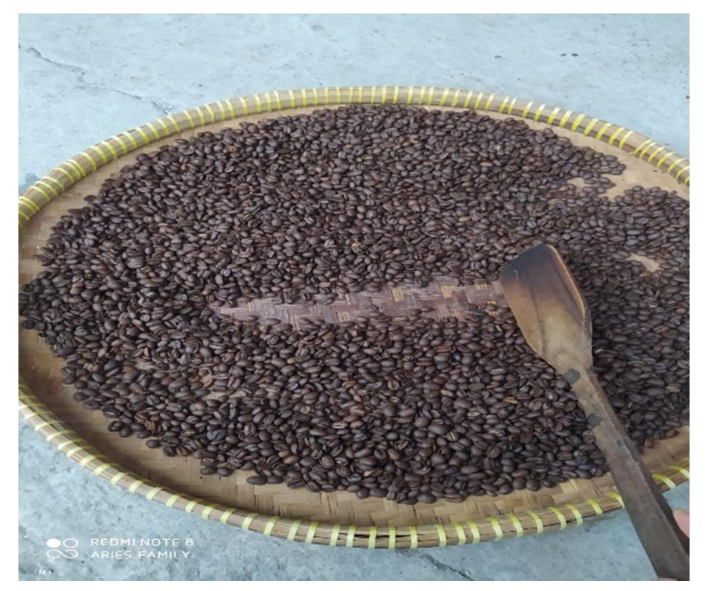

Gambar 1. Biji kopi

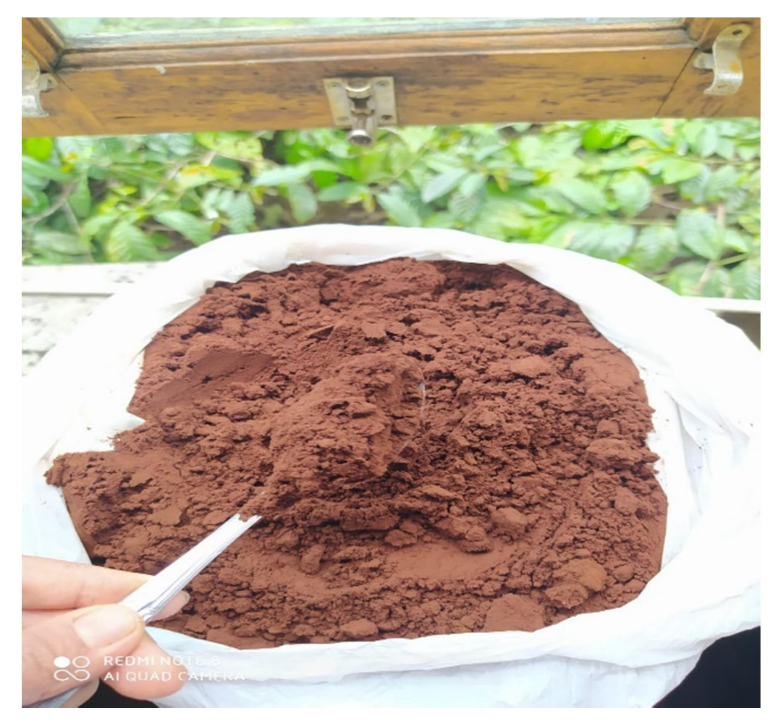

Gambar 2. Bubuk kopi

Berdasarkan hasil wawancara peneliti dengan ketua Kelompok Wanita Tani Suka Makmur I, perusahaan memiliki permasalahan pada strategi pemasaran produk. Sebelum memasuki pandemi covid-19, perusahaan dapat memasarkan produk kopi sebesar $11 \mathrm{~kg}$ pada setiap harinya. Namun, terhitung pada bulan Januari 2020 hingga bulan Juni 2020 penjualan kopi pada satu hari hanya mencapai $5 \mathrm{~kg}$. Pemasaran kopi merupakan salah satu kegiatan yang sangat penting dalam dunia usaha. Pada kondisi sekarang ini, pemasaran merupakan pendorong untuk meningkatkan penjualan sehingga tujuan perusahaan dapat tercapai. Kegiatan pemasaran kopi yang dilakukan tidak lepas dari berbagai kendala baik secara internal maupun eksternal dari Kelompok Wanita Tani Suka Makmur I. 
Tabel 1. Produksi Kopi di Provinsi Jawa

\begin{tabular}{ccc} 
& Tengah & \\
\hline No & Tahun & Produksi \\
\hline 1 & 2016 & 18,911 ton \\
2 & 2017 & 17,197 ton \\
3 & 2018 & 23,686 ton \\
4 & 2019 & 24,063 ton \\
5 & 2020 & 24,456 ton \\
\hline
\end{tabular}

Sumber : Direktorat Jendral Perkebunan

Dari data lima tahun terakhir di Provinsi Jawa Tengah, perkembangan kopi mengalami kenaikan produksi yang cukup pesat, pada tahun 2018 produksi kopi mencapai sekitar 23,686 ribu ton dan pada tahun 2020 produksi kopi sekitar 24,456 ribu ton. Sehingga produksi kopi di Provinsi Jawa Tengah dari tahun 2016-2020 mengalami kenaikan sekitar 37,74\% (Kementerian Republik Indonesia).

Persaingan yang semakin ketat dengan perusahaan sejenis maupun perusahaan dengan produk subtitusinya kini membuat Kelompok Wanita Tani Suka Makmur I sulit memasuki pasar. Hal ini merupakan salah satu permasalahan yang dihadapi oleh Kelompok Wanita Tani Suka Makmur I. Perbandingan antara jumlah produksi dengan jumlah penjualan tiap bulannya selalu mengalami ketimpangan, dimana jumlah penjualan selalu lebih rendah daripada jumlah produksi. Artinya, perusahaan masih belum mampu memasarkan produknya sesuai dengan target produksi. Perbedaan nilai ini selalu terjadi pada setiap bulannya yang juga merupakan suatu permasalahan yang dihadapi oleh Kelompok Wanita Tani Suka Makmur I dalam bidang pemasaran. Pemilihan strategi yang tepat dalam proses pemasaran akan sangat mempengaruhi visi dan misi Kelompok Wanita Tani Suka Makmur I. Dalam hal ini, Kelompok Wanita Tani Suka Makmur I harus memilih dan menerapkan strategi-strategi pemasaran yang tepat dalam kegiatan pemasaran produk kopi. Untuk itu, diperlukan suatu penelitian mengenai strategi pemasaran Kopi Kelompok Wanita Tani Suka Makmur I.

Berdasarkan cara kerjanya, pengolahan buah kopi dibedakan menjadi 2 macam, yaitu pengolahan basah (wet process) dan kering (dry process) (Bonita et al, 2007). Perbedaan tersebut terletak pada cara kering, pengupasan daging buah, kulit tanduk dan kulit ari dilakukan setelah kering sedangkan pada cara basah, pengupasan daging buah dilakukan sewaktu masih basah. Pengolahan cara kering biasanya dilakukan oleh petani kopi (rakyat) karena dapat dilakukan dengan peralatan sederhana. Cara pengolahan ini meliputi panen, sortasi buah, pengeringan, 
pengupasan, sortasi biji kering, pengemasan dan penyimpanan biji kopi. Pengolahan secara basah biasanya dilakukan oleh perkebunan kopi skala besar. Cara pengolahan kopi secara basah dapat menghasilkan mutu fisik kopi yang baik. Akan tetapi, cita rasa alami kopi akan berkurang karena keterlibatan air selama proses pengolahan (Rahardjo, 2012)

Swastha dan Irawan (2008) menyatakan bahwa strategi adalah serangkaian rancangan besar yang menggambarkan bagaimana sebuah perusahaan harus beroperasi untuk mencapai tujuannya, sehingga dalam menjalankan usaha kecil khususnya diperlukan adanya pengembangan melalui strategi pemasarannya. Karena pada saat kondisi kritis justru usaha kecillah yang mampu memberikan pertumbuhan terhadap pendapatan masyarakat. Dengan kata lain, strategi adalah suatu sarana yang digunakan untuk mencapai tujuan akhir. Menurut Kotler (2000), strategi pemasaran adalah pola pikir pemasaran yang akan digunakan untuk mencapai tujuan pemasarannya. Olson dan Peter (2013) berpendapat bahwa strategi pemasaran merupakan desain, implementasi dan kontrol rencana untuk memengaruhi pertukaran demi mencapai tujuan organisasi.

Menurut Jauch \& Glueck (1998), lingkungan internal merupakan lingkungan yang berada di dalam suatu organisasi atau perusahaan yang secara normal memiliki implikasi langsung dan khusus pada perusahaan tersebut. Analisis lingkungan internal suatu perusahaan atau organisasi dapat diartikan suatu proses atau cara perencanaan strategi yang mencakup pada bidang produksi, pemasaran dan distribusi, keuangan serta sumber daya manusia dalam perusahaan atau organisasi tersebut. Menganalisis lingkungan internal perusahaan dapat dimulai dari memahami kekuatan dan kelemahan dari masing-masing bidang tersebut, sehingga didapat cara untuk memanfaatkan peluang dari luar perusahaan serta dapat menangani ancaman dari luar perusahaan.

Menurut Duncan lingkungan eksternal merupakan faktorfaktor yang berasal dari luar perusahaan yang memiliki pengaruh terhadap operasional perusahaan sehingga dipertimbangkan dalam pembuatan keputusan. David (2009) mengemukakan bahwa faktor-faktor yang berasal dari eksternal perusahaan yang digunakan 
untuk menganalisis lingkungan eksternal dibagi menjadi lima aspek, yaitu: aspek ekonomi, aspek sosial, aspek politik, aspek teknologi dan aspek kompetitif (persaingan).

\section{METODE PENELITIAN}

Penelitian dilaksanakan di Kelompok Wanita Tani Suka Makmur I, Kabupaten Semarang. Lokasi penelitian dipilih secara sengaja (purposive) atas dasar pertimbangan bahwa wilayah tersebut berpotensi untuk menganalisis strategi pemasaran. Waktu pelaksanaan pengumpulan data dilakukan selama dua bulan, yaitu pada bulan September dan Oktober 2020. Penelitian ini merupakan penelitian deskriptif kualitatif. Deskriptif merupakan suatu jenis penelitian suatu objek, kondisi, pemikiran ataupun suatu peristiwa pada masa sekarang (Nazir 2009). Metode penelitian kualitatif adalah suatu metode pendekatan atau penelusuran untuk mengeksplorasi dan memahami suatu gejala sentral. Untuk mengerti gejala sentral tersebut peneliti mewawancarai informan atau partisipan dengan mengajukan pertanyaan yang umum dan agak luas (Raco, 2010).

Narasumber dalam penelitian ini meliputi dua macam, yaitu informan kunci (key informant) adalah seseorang yang memiliki informasi pokok serta memahaminya sehingga dapat membagikan informasi yang diperlukan dalam penelitian, dan informan adalah seseorang yang terlibat langsung dalam kegiatan yang berkaitan dengan topik penelitian. Informan kunci yang dipilih dalam penelitian ini sebanyak 1 orang, yaitu bidang pemasaran dan informan pada penelitian ini sebanyak 1 orang, yaitu Ketua Kelompok Wanita Tani Suka Makmur I.

Uji data menggunakan triangulasi sumber dan triangulasi teknik. Triangulasi sumber untuk menguji kredibilitas data dengan cara mengecek data yang telah diperoleh melalui beberapa sumber. Data setelah mewawancarai informan-informan tidak bisa dirata-ratakan seperti dalam penelitian kuantitatif, tetapi dideskripsikan, dikategorikan, mana pandangan yang sama mana yang berbeda. Data yang telah dianalisis oleh peneliti selanjutnya dimintakan kesepakatan (member check) dengan tiga sumber data yakni informan kunci dan informan pendukung. Sedangkan triangulasi teknik merupakan cara untuk menguji kredibilitas data dengan mengecek data yang diperoleh dengan teknik yang berbeda. Sebagai contoh, 
awal pengambilan data menggunakan wawancara, lalu dicek dengan observasi atau dokumentasi. Apabila data yang diperoleh berbeda dengan data awal, maka dilakukan diskusi lebih lanjut bersama sumber data yang bersangkutan untuk memastikan data yang dianggap benar (Sugiyono, 2011). Triangulasi teknik adalah informan utama dari partisipan, dikuatkan oleh informan kunci dan informan. Input utama analisis SWOT dan QSPM adalah ketua Kelompok Tani Suka Makmur I dan informan pendukung lainnya adalah anggota dan konsumen Kelompok Wanita Tani Suka Makmur I.

Analisis data yang digunakan adalah tahap pertama input data menggunakan matriks IFE dan matriks EFE, tahap kedua pencocokan data menggunakan matriks IE dan matriks SWOT, lalu tahap ketiga pengambilan keputusan menggunakan matriks QSPM. Alat yang digunakan untuk menganalisis data pada tahap input adalah matriks IFE dan matriks EFE. Matriks IFE berhubungan dengan tingkat kepentingan relatif dari faktor-faktor kekuatan dan kelemahan dalam perusahaan, sedangkan matriks EFE berhubungan dengan tingkat kepentingan relatif dari faktor-faktor peluang dan ancaman luar perusahaan.
Data yang didapat dari matriks IFE dan EFE akan digunakan untuk dasar analisis pada tahap pengolahan data dan keputusan.

Teknik yang digunakan untuk mengolah data dari hasil input ke perumusan strategi adalah matriks IE dan matriks SWOT. Matriks IE dibuat berdasarkan skor bobot IFE pada sumbu horizontal dan skor bobot EFE pada sumbu vertikal. Matriks IE dikelompokkan menjadi tiga kelompok yang memiliki perencanaan strategi yang berbeda tiap kelompoknya. Pertama kelompok I, II dan IV digambarkan tumbuh dan membangun, pilihan strategi seperti pengembangan pasar dan pengembangan produk merupakan pilihan yang tepat. Kedua kelompok III, $\mathrm{V}$ dan VII digambarkan menjaga dan mempertahankan. Lalu yang ketiga kelompok VI, VIII dan IX diartikan divestasi perusahaan (pengurangan aset perusahaan). Matriks SWOT merupakan alat untuk mencocokan data faktor internal dan eksternal sehingga dapat membantu merumuskan strategi pengembangan yang tepat. 


\section{HASIL DAN PEMBAHASAN}

Potensi dan tantangan kopi yang dihasilkan Kelompok Wanita Tani Suka Makmur I

Usaha pengolahan kopi yang dilakukan oleh kelompok wanita tani Suka Makmur I memiliki potensi untuk dikembangkan lebih lanjut di masa mendatang. Berdasarkan hasil wawancara beberapa hal yang merupakan potensi usaha pengolahan kopi Kelompok Wanita Tani Suka Makmur I adalah:

1. Produk kopi Gumuk Dalli tidak membutuhkan bahan baku dari luar karena memiliki kebun budidaya sendiri dari kelompok tani, sehingga aspek keberlanjutan bahan baku terjamin

2. KWT telah memiliki pengalaman selama 7 tahun berdiri sehingga manajemen, ketersediaan modal kerja, dan investasi alat terjamin

3. Memiliki setifikasi HACCP dan RA.

4. Produk kopi Gumuk Dalli sudah bisa bersaing dengan produk kopi lainnya, baik dalam kualitas harga maupun kualitas mutu produk

5. Fasilitas produksi sudah terkelola dengan baik.

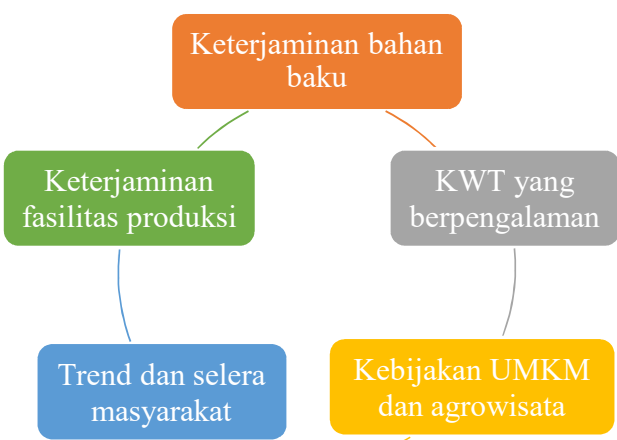

Gambar 3. Potensi dan Pengembangan

Tantangan adalah kondisi dimana menyebabkan usaha pengolahan kopi yang dihasilkan KWT Suka Makmur I terancam. Berdasarkan hasil wawancara beberapa hal yang merupakan potensi usaha pengolahan kopi Kelompok Wanita Tani Suka Makmur I adalah:

1. Belum melakukan promosi secara efektif

2. Belum melakukan riset pasar di luar Kecamatan Sumowono

3. Pemantauan kualitas biji kopi yang masih kurang

Pengolahan kopi belum

menggunakan teknologi secara penuh

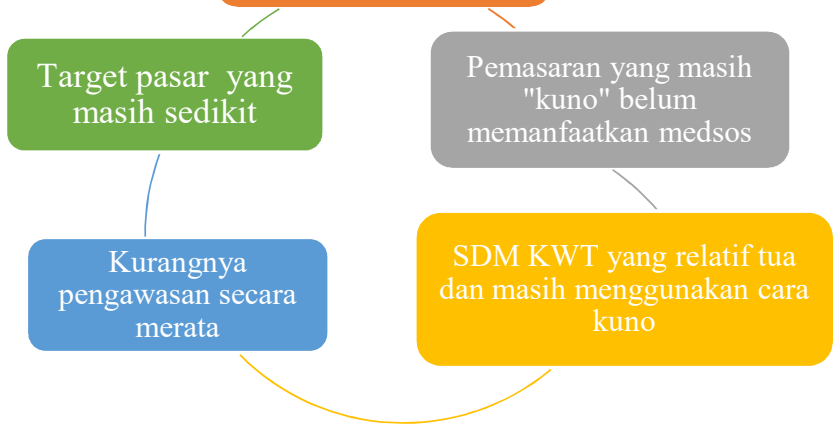

Gambar 4. Tantangan dan Pengembangan 
Tabel 2. Produksi Kopi di Provinsi Jawa

\begin{tabular}{ccc} 
& Tengah & \\
\hline No & Tahun & Produksi \\
\hline 1 & 2017 & 17,196 ton \\
2 & 2018 & 23,686 ton \\
3 & 2019 & 24,732 ton \\
4 & 2020 & 24,922 ton \\
5 & 2021 & 25,136 ton \\
\hline
\end{tabular}

Sumber: Direktorat Jendral Perkebunan 2015

Perkembangan kopi di Jawa Tengah selama 5 tahun terakhir mengalami peningkatan yang cukup pesat. Pada tahun 2018 produksi kopi mencapai 23,686 ribu ton, dan pada tahun 2021 produksi kopi mencapai 25,136 ribu ton. Sehingga produksi kopi di Provinsi Jawa Tengah dari tahun 2017-2021 mengalami kenaikan sekitar 4,41\% (Kementerian Republik Indonesia)

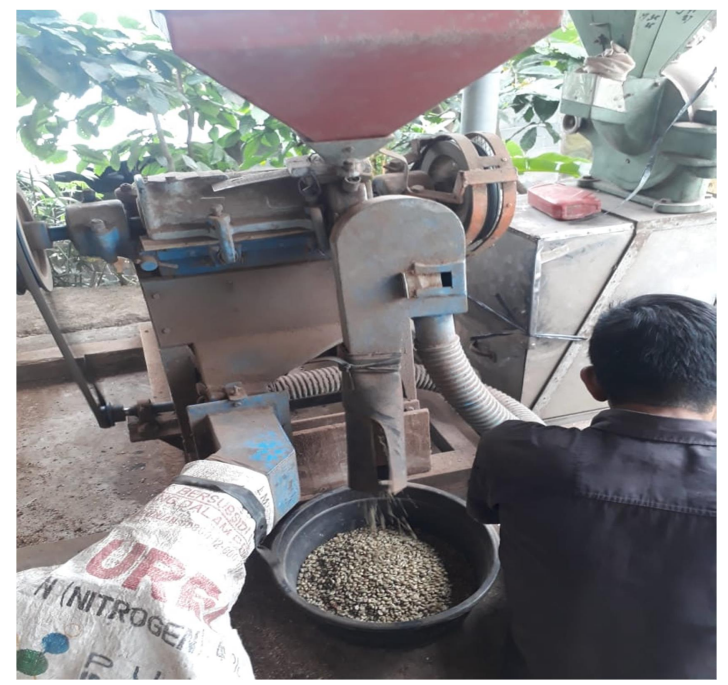

Gambar 3. Alat pengupas kulit kopi

Perkembangan alat pertanian yang semakin maju di KWT Suka Makmur I akan memudahkan para karyawan untuk mengerjakan pekerjaan. Salah satu alat pengupas kulit kopi yang dimiliki oleh
KWT Suka Makmur I seperti pada Gambar 3. Selain alat pengupas kulit kopi, KWT Suka Makmur I juga memiliki pulper, buhler, alat roasting dan pengetes kadar air. Tenaga kerja yang dimiliki oleh Kelompok Wanita Tani Suka Makmur I berjumlah 7 anggota organisasi, 11 anggota aktif, dan lebih dari 50 orang kelompok tani kopi.

\section{Identifikasi Faktor Internal Kelompok Wanita Tani Suka Makmur I}

Analisis faktor internal di Kelompok Wanita Tani Suka Makmur I menghasilkan 12 faktor kekuatan dan 5 faktor kelemahan yang dimanfaatkan untuk mengambil peluang serta mengatasi ancaman dari luar perusahaan. Hasil dari analilis faktor-faktor internal didapat dari analisis lingkungan internal yang mencakup aspek manajemen, pemasaran, keuangan, dan produksi. Faktor-faktor kekuatan dan kelemahan internal Kelompok Wanita Tani Suka Makmur I diuraikan pada Tabel 1.

Kekuatan utama yang ada pada Kelompok Wanita Tani Suka Makmur I adalah pembagian jobdesk sudah sesuai dengan tugasnya masing-masing secara tepat, dengan nilai skor 0,282. Pembagian jobdesk yang baik dan merata dapat memberikan motivasi kepada karyawan dan memudahkan karyawan dalam 
bekerja. Karyawan akan lebih termotivasi

jika semua bagian saling mengingatkan

dan memperhatikan satu sama lain, dengan begitu maka akan memperoleh hasil kerja yang optimal pada setiap bagian. Kelemahan utama pada Kelompok Wanita Tani Suka Makmur I adalah pemantauan tanaman kopi yang masih kurang, dengan nilai skor 0,134.
Pekerja belum melakukan pemantauan secara maksimal merupakan salah satu faktor penghambat dalam melaksanakan kegiatan perkebunan kopi, karena dengan kurangnya pemantauan dapat mengakibatkan hasil panen yang kurang baik akibat hama atau iklim yang tidak menentu.

Tabel 3. Matriks IFE Kelompok Wanita Tani Suka Makmur I

\begin{tabular}{|c|c|c|c|c|}
\hline No & Faktor Internal & Bobot & Rating & Skor \\
\hline \multicolumn{5}{|c|}{ Kekuatan } \\
\hline 1 & $\begin{array}{l}\text { Pembagian jobdesk sudah sesuai dengan tugasnya masing- } \\
\text { masing secara tepat }\end{array}$ & 0,070 & 4 & 0,282 \\
\hline 2 & $\begin{array}{l}\text { Kegiatan Kelompok Wanita Tani Suka Makmur I sudah } \\
\text { berjalan baik karena sudah terdapat rancangan kegiatan secara } \\
\text { teratur setiap tahun dan evaluasi kegiatan secara teratur }\end{array}$ & 0,068 & 3 & 0,203 \\
\hline 3 & Terdapat pemotivasian kepada karyawan secara teratur & 0,065 & 3 & 0,195 \\
\hline 4 & Memiliki sertifikasi HACCP dan RA & 0,063 & 3 & 0,190 \\
\hline 5 & $\begin{array}{l}\text { Manajemen keuangan sudah baik dari segi pembagian anggaran } \\
\text { setiap bagian dan evaluasi anggaran telah terlaksana dengan } \\
\text { baik }\end{array}$ & 0,069 & 4 & 0,275 \\
\hline 6 & Fasilitas produksi sudah terkelola dengan baik & 0,066 & 4 & 0,264 \\
\hline 7 & $\begin{array}{l}\text { Kopi Gumuk Dalli tidak memerlukan bahan baku dari luar } \\
\text { karena memiliki kebun budidaya sendiri }\end{array}$ & 0,053 & 4 & 0,211 \\
\hline 8 & Memiliki komoditas kopi jenis unggulan & 0,070 & 4 & 0,211 \\
\hline 9 & $\begin{array}{l}\text { Pekerja sudah memenuhi standar operasional prosedur seperti } \\
\text { menggunakan masker, sarung tangan dan sepatu }\end{array}$ & 0,053 & 3 & 0,158 \\
\hline 10 & $\begin{array}{l}\text { Taste dari produk kopi Gumuk Dalli lebih unggul rasa kafein } \\
\text { dan memiliki aroma kopi yang kuat dibanding taste produk kopi } \\
\text { lain }\end{array}$ & 0,070 & 3 & 0,211 \\
\hline 11 & $\begin{array}{l}\text { Produk kopi Gumuk Dalli sudah bisa bersaing dengan produk } \\
\text { kopi lainnya, baik dalam kualitas harga maupun kualitas mutu } \\
\text { produk. }\end{array}$ & 0,053 & 3 & 0,158 \\
\hline 12 & $\begin{array}{l}\text { Produk kopi yang dikelola oleh KWT Suka Makmur I memiliki } \\
\text { variasi jenis kopi bubuk dan kopi biji serta rasa pahit yang kuat }\end{array}$ & 0,068 & 3 & 0,203 \\
\hline \multicolumn{5}{|c|}{ Kelemahan } \\
\hline 13 & $\begin{array}{l}\text { Lebih mengutamakan kesenioran sehingga tenaga kerja yang } \\
\text { lebih lama bekerja diprioritaskan }\end{array}$ & 0,070 & 3 & 0,211 \\
\hline 14 & Belum ada penentu persentase penjualan & 0,040 & 2 & 0,079 \\
\hline 15 & $\begin{array}{l}\text { Belum melakukan riset pasar ke konsumen di luar Kecamatan } \\
\text { Sumowono terkait produk kopi kemasan }\end{array}$ & 0,033 & 2 & 0,067 \\
\hline 16 & Belum melakukan promosi secara efektif & 0,042 & 2 & 0,085 \\
\hline \multirow[t]{2}{*}{17} & Pemantauan kualitas biji kopi yang masih kurang & 0,046 & 2 & 0,092 \\
\hline & Total & & & $\mathbf{3 . 0 9 7}$ \\
\hline
\end{tabular}

Sumber: Data primer (2020) 


\section{Identifikasi Faktor Eksternal Kelompok Wanita Tani Suka Makmur I}

Analisis faktor eksternal di Kelompok Wanita Tani Suka Makmur I menghasilkan 7 faktor peluang dan 3 faktor ancaman yang dimanfaatkan untuk mengambil peluang serta mengatasi ancaman dari luar perusahaan. Hasil dari analilis faktor-faktor internal didapat dari analisis lingkungan eksternal yang mencakup aspek manajemen, pemasaran, keuangan, dan produksi. Faktor-faktor kekuatan dan kelemahan internal Kelompok Wanita Tani Suka Makmur I diuraikan pada Tabel 2.

Tabel 4. Matriks IFE Kelompok Wanita Tani Suka Makmur I

\begin{tabular}{|c|c|c|c|c|}
\hline No & Faktor Eksternal & Bobot & Rating & Skor \\
\hline \multicolumn{5}{|c|}{ Peluang } \\
\hline 1 & $\begin{array}{l}\text { Permintaan kopi dalam negeri meningkat, namun jumlah pemasok } \\
\text { masih sedikit }\end{array}$ & 0,136 & 3 & 0,407 \\
\hline 2 & $\begin{array}{l}\text { Belum memiliki pajak kepada pemerintah sehingga dana } \\
\text { dialokasikan ke modal perusahaan }\end{array}$ & 0,108 & 3 & 0,323 \\
\hline 3 & $\begin{array}{l}\text { Tempat budidaya kopi yang baik dengan ketinggian 1.000-1.100 } \\
\text { mdpl }\end{array}$ & 0,115 & 3 & 0,344 \\
\hline 4 & $\begin{array}{l}\text { Masyarakat sekitar perusahaan mendukung adanya Kelompok } \\
\text { Wanita Tani Suka Makmur I }\end{array}$ & 0,111 & 3 & 0,333 \\
\hline 5 & Pemandangan alam yang bagus di daerah Kecamatan Sumowono & 0,076 & 4 & 0,304 \\
\hline 6 & $\begin{array}{l}\text { Perkembangan alat teknologi kopi yang memudahkan petani dalam } \\
\text { mengolah kopi }\end{array}$ & 0,069 & 3 & 0,207 \\
\hline 7 & Perusahaan lain membuka peluang untuk bekerja sama & 0,104 & 4 & 0,402 \\
\hline \multicolumn{5}{|c|}{ Ancaman } \\
\hline 8 & $\begin{array}{l}\text { Perubahan cuaca yang tidak menentu menyebabkan produktifitas } \\
\text { menurun }\end{array}$ & 0,063 & 3 & 0,189 \\
\hline 9 & Banyak produk kopi lan yang sudah lebih dikenal oleh masyarakat & 0,056 & 3 & 0,168 \\
\hline 10 & $\begin{array}{l}\text { Harga produk kopi lain lebih murah daripada produk kopi Gumuk } \\
\text { Dalli }\end{array}$ & 0,167 & 3 & 0,501 \\
\hline & Total & & & 3,177 \\
\hline
\end{tabular}

Sumber: Data primer (2020)

Peluang utama yang ada pada Kelompok Wanita Tani Suka Makmur I adalah permintaan kopi dalam negeri meningkat namun jumlah pemasok kopi masih sedikit, dengan nilai skor 0,407. Variabel tersebut merupakan variabel faktor eksternal dalam segi peluang yang paling penting karena Kelompok Wanita Tani Suka Makmur I memiliki peluang untuk dapat memasok kopi dengan kualitas yang lebih. Selain itu, dengan jumlah penjualan yang lebih tinggi akan menghasilkan keuntungan yang tinggi, sehingga mampu menambah pendapatan untuk kas perusahaan. Ancaman utama yang ada di Kelompok Wanita Tani Suka Makmur I adalah harga produk kopi lain lebih rendah daripada produk kopi Gumuk Dalli, dengan skor 0,501. Harga produk kopi lain yang lebih rendah 
merupakan salah satu ancaman utama untuk produk kopi Gumuk Dalli, karena kebanyakan masyarakat akan lebih memilih kopi yang sudah dulu dikenal

\section{Hasil Analisis Matriks QSPM}

Tabel 5. Analisis matriks QSPM

\begin{tabular}{|c|c|c|}
\hline Strategi & Nilai STAS & Peringkat \\
\hline $\begin{array}{l}\text { Strategi } 1 \\
\text { Meningkatkan kualitas produk kopi Gumuk Dalli }\end{array}$ & 11.171 & 2 \\
\hline $\begin{array}{l}\text { Starategi } 2 \\
\text { Mengedukasi masyrakat tentang kopi dari budidaya hingga ciri-ciri produk } \\
\text { kopi yang terbaik }\end{array}$ & 9.912 & 4 \\
\hline $\begin{array}{l}\text { Strategi } 3 \\
\text { Menjalin kerja sama dengan distributor yang potensial untuk menambah } \\
\text { pangsa pasar }\end{array}$ & 9.065 & 1 \\
\hline $\begin{array}{l}\text { Strategi } 4 \\
\text { Melatih karyawan sesuai dengan bidang keahliannya dan menetapkan aturan } \\
\text { serta memberikan sanksi yang tegas apabila melanggar aturan }\end{array}$ & 11.224 & 10 \\
\hline $\begin{array}{l}\text { Strategi } 5 \\
\text { Memperluas area penjualan kopi Gumuk Dalli dengan melakukan ekspansi } \\
\text { di tempat Wisata Kecamatan Sumowono }\end{array}$ & 8.833 & 5 \\
\hline $\begin{array}{l}\text { Strategi } 6 \\
\text { Penggunaan peralatan terkini untuk meningkatkan kualitas produk }\end{array}$ & 10.162 & 9 \\
\hline $\begin{array}{l}\text { Strategi } 7 \\
\text { Menambah lahan budidaya kopi atau petani-petani mitra }\end{array}$ & 10.937 & 8 \\
\hline $\begin{array}{l}\text { Strategi } 8 \\
\text { Menambah produk pengembangan dari kopi Gumuk Dalli seperti kopi siap } \\
\text { minum }\end{array}$ & 10.635 & 7 \\
\hline $\begin{array}{l}\text { Strategi } 9 \\
\text { Meningkatkan promosi dengan membuat iklan yang menarik serta memiliki } \\
\text { ciri khas dari produk kopi Gumuk Dalli }\end{array}$ & 10.100 & 3 \\
\hline $\begin{array}{l}\text { Strategi } 10 \\
\text { Membuka cabang retail baru di luar Kecamatan Sumowono }\end{array}$ & 8.833 & 6 \\
\hline
\end{tabular}

Sumber: Data Primer (2020)

Berdasarkan hasil analisis matriks QSPM pada tabel diatas dapat dilihat prioritas alternatif strategi yang berkaitan dengan analisis strategi pemasaran Kelompok Wanita Tani Suka Makmur I, berikut urutan alternatif strategi dari nilai STAS tertinggi hingga terendah ; oleh masyarakat dan dengan harga yang murah. 
4. Memperluas area penjualan produk Gumuk Dalli dengan melakukan ekspansi di tempat wisata Kecamatan Sumowono (10.635).

5. Meningkatkan promosi dengan membuat iklan yang unik dan menarik serta memiliki ciri khas produk Gumuk Dalli (10.162).

6. Menambah lahan budidaya kopi atau petani-petani mitra (10.100).

7. Melatih karyawan sesuai dengan bidang keahliannya dan menetapkan aturan serta memberikan sanksi yang tegas apabila melanggar aturan (9.912).

8. Penggunaan peralatan terkini untuk meningkatkan kualitas produk (9.446)

9. Menambah produk pengembangan dari kopi Gumuk Dalli seperti kopi siap minum (9.065).

10. Membuka cabang retail di luar Kecamatan Sumowono (8.833).

\section{KESIMPULAN}

1. Usaha pengolahan kopi memiliki potensi, terutama (1) produk kopi Gumuk Dalli tidak membutuhkan bahan baku dari luar karena memiliki kebun budidaya sendiri dari kelompok tani, sehinga aspek keberlanjutan bahan baku terjamin, (2) KWT telah memiliki pengalaman selama 7 tahun berdiri sehingga manajemen ketersediaan modal kerja dan investasi alat terjamin, (3) Memiliki surat sertifikasi HACCP dan RA, (4) Produk kopi sudah bisa bersaing dengan produk kopi lainnya, baik dalam kualitas harga maupun kualitas mutu produk dan tantangan utama antara lain, (5) Belum melakukan promosi secara efektif, (6) Belum melakukan riset pasar di luar Kecamatan Sumowono, dan (7) Pemantauan kualitas biji kopi yang masih kurang. Sehingga memerlukan strategi pengembangan lebih lanjut.

2. Posisi Kelompok Wanita Tani Suka Makmur I pada analisis matriks IE berada di sel I yaitu kondisi internal kuat dan eksternal yang tinggi, sehingga dapat menggunakan strategi tumbuh dan membangun (growth and build) untuk menentukan alternatif strategi yang sesuai dengan keadaan Kelompok Wanita Tani Suka Makmur I saat ini. Hasil analisis matriks SWOT menghasilkan sepuluh alternatif pilihan strategi pemasaran kopi Kelompok Wanita Tani Suka Makmur I yang kemudian diurutkan sesuai dengan peringkat melalui analisis QSPM. Alternatif strategi yang dipiroritaskan dan mendapat 
nilai STAS tertinggi adalah menjalin kerja sama dengan distributor yang potensial untuk menambah pangsa pasar. Selain itu, alternatif pilihan strategi yang direkomendasikan kepada Kelompok Wanita Tani Suka Makmur I adalah sebagai berikut: (1) Meningkatkan kualitas mutu produk kopi Gumuk Dalli (11.171),

Mengedukasi masyarakat tentang kopi dari mulai budidaya hingga ciriciri produk kopi terbaik (10.937), (3) Memperluas area penjualan produk Gumuk Dalli dengan melakukan ekspansi di tempat wisata Kecamatan Sumowono (10.635),

Meningkatkan promosi dengan membuat iklan yang unik dan menarik serta memiliki ciri khas produk Gumuk Dalli (10.162), (5) Menambah lahan budidaya kopi atau petani-petani mitra (10.100), (6) Melatih karyawan sesuai dengan bidang keahliannya dan menetapkan aturan serta memberikan sanksi yang tegas apabila melanggar aturan (9.912), (7) Penggunaan peralatan terkini untuk meningkatkan kualitas produk (9.446), (8) Menambah produk pengembangan dari kopi Gumuk Dalli seperti kopi siap minum (9.065), dan (9) Membuka cabang retail di luar Kecamatan Sumowono (8.833)

\section{DAFTAR PUSTAKA}

Bonita, J.S., Mandarano, M., Shuta, D. and Vinson, J., 2007. Coffee and cardiovascular disease: in vitro, cellular, animal, and human studies. Pharmacological research, 55(3), pp.187-198

David, Fred. 2009. Manajemen Strategis Konsep, Buku 1, Edisi 12. Jakarta: Selemba Empat.

Direktorat Jenderal Perkebunan. 2014. Statistik Perkebunan Indonesia: Kopi 2013-2015. Kementerian Pertanian. Jakarta.

Direktorat Jenderal Perkebunan. 2015. Statistik Perkebunan Indonesia: Kopi 2014-2016. Kementerian Pertanian. Jakarta.

Duncan, R. 1972. "Characteristic of Organizational Environments and Precieved Environmental Uncertanty." Administrative Science Quaterly Vol 17.

Jauch, Lawrance R., dan WIlliam F Glueck. 1998. Manajemen Strategis dan Kebijakan Perusahaan, edisi ke-3. Jakarta: Erlangga.

Kotler, P. 2000. Manajemen Pemasaran, edisi millenium. Jakarta: Prenahallindo.

Rahardjo, P. 2012. Panduan Budidaya dan Pengolahan Kopi Arabika dan Robusta. Penebar Swadaya. Jakarta.

Nazir, M. 2009. Metode Penelitian Cetakan Ketujuh. Bogor: Ghalia Indonesia.

Peter, J. Paul dan Olson, Jerry C., 2013. Perilaku Konsumen \& Strategi Pemasaran. Jakarta: Salemba Empat. 
Pusat Data dan Sistem Informasi Pertanian. 2016. Outlook KomoditiKopi. Kementerian Pertanian. Jakarta.

Raco, J, R. 2010. Metode Penelitian Kualitatif. Jakarta: PT Gramedia Widiasarana Indonesia.

Sugiyono. 2011. Metode Penelitian Kuantitatif Kualitatif dan R\&D. Bandung : Alfabeta
Sugiyono. 2012. Metode Penelitian Administrasi dilengkapi dengan Metode $\mathrm{R}$ dan $\mathrm{D}$. Bandung: Penerbit

Sugiyono. 2014. Metode Penelitian Kuantitatif, Kualitatif, dan Kombinasi (Mixed Methods). Bandung : Alfabeta

Swstha, Basu dan Irawan, 2008. Manajemen Pemasaran Modern. Yogyakarta: Liberty Offset. 